\title{
PENGARUH WAKTU PERENDAMAN PADA REBUNG BETUNG (Dendrocalamus asper) TERHADAP PENURUNAN KADAR SIANIDA
}

\author{
Nur Qadri Rasyid ${ }^{1)}$ Muh. Rifo Rianto ${ }^{1)}$ Ita Reski Cahyani ${ }^{1)}$ \\ 1) Politeknik Kesehatan Muhammadiyah Makassar \\ Alamat Korespondensi: nqadrir@gmail.com
}

\begin{abstract}
Abstrak
Rebung betung (Dendrocalamus asper) memiliki kandungan nutrisi, namun di samping itu rebung juga mengandung unsur anti nutrisi yang membahayakan kesehatan yaitu kandungan hidrogen sianida (HCN). Asam sianida merupakan senyawa beracun yang sangat mematikan, apabila masuk kedalam tubuh dalam dosis yang tinggi maka akan menyebabkan gangguan kesehatan bahkan kematian dalam sekejap. Tujuan penelitian ini untuk mengetahui pengaruh waktu perendaman pada rebung betung (Dendrocalamus asper) terhadap penurunan kadar sianida dengan variasi waktu 0 menit,15 menit, 30 menit, 45 menit dan 1 jam. Pada penelitian ini menggunakan metode eksperimen laboratorik yang diuji secara kuantitatif dengan menggunakan alat spektrofotometer UV-Vis. Hasil penelitian ini menunjukkan bahwa kadar sianida pada perendaman 0 menit diperoleh kadar sianida sebanyak 64,07 mg/kg dengan selisih 0, pada perendaman 15 menit diperoleh kadar sebanyak sianida sebanyak $49,78 \mathrm{mg} / \mathrm{kg}$ dengan selisih sebanyak 14,29 pada perendaman 30 menit didapatkan kadar sianida sebanyak 45,15 mg/kg dengan selisih sebanyak 18,92 mg/kg, pada perendaman 45 menit didapatkan kadar sianida sebanyak 44,85 mg/kg dengan selisih sebanyak $19,22 \mathrm{mg} / \mathrm{kg}$ dan penurunan kadar sianida tertinggi yaitu pada perendaman selama 1 jam sebanyak 43,83 mg/kg dengan selisih sebanyak 20,24 mg/kg. Sehingga dapat disimpulkan bahwa waktu perendaman rebung mempengaruhi kadar sianida pada rebung, semakin lama waktu perendaman kadar sianida semakin menurun sehingga masih aman untuk dikonsumsi karena tidak melewati ambang batas yang telah ditentukan yaitu $<50 \mathrm{mg} / \mathrm{kg}$.
\end{abstract}

Kata Kunci : Rebung, Sianida, Spektrofotometer UV Vis

\section{PENDAHULUAN}

Indonesia merupakan salah satu negara di dunia yang memiliki kekayaan alam cukup besar terutama dalam bidang sumber daya alam. Salah satu sumber daya alam yang dimiliki adalah aneka ragam tanaman yang dapat dimanfaatkan baik sebagai obat-obatan, tanaman hias maupun sebagai bahan makanan yang dapat dikonsumsi sehari-hari, salah satunya adalah rebung. Rebung merupakan salah satu makanan yang cukup popular dimasyarakat. Di Indonesia beberapa produk pangan yang menggunakan bahan rebung antara lain gudeg, lumpia, urap, rebung fermentasi, sayur lodeh dan lainlain (Andoko, 2003).

Rebung sudah lama dikenal dan digemari seluruh lapisan masyarakat, baik dipedesaan maupun diperkotaan. Selama ini mayoritas masyarakat mengkonsumsi rebung dengan dibuang kelopaknya, diirisiris, kemudian diolah dengan cara dikukus atau direbus. Rebung yang sering dikenal dengan nama bung (bahasa Jawa), oleh masyarakat pedesaan sudah sejak zaman dahulu dimanfaatkan sebagai bahan masakan. Rebung digolongkan kedalam sayuran, tapi untuk menambah nilai 
jualnya maka dapat dibuat menjadi berbagai macam olahan. Ukuran rebung di setiap lokasi berbeda-beda tergantung pada beberapa faktor seperti tempat tumbuhnya, nutrisi tanah, curah hujan, suhu, serta kesuburan tanah. Tanaman ini tersebar di daerah tropis, sub tropis dan daerah beriklim sedang. Terdapat sekitar 145 jenis bambu yang merupakan asli Indonesia dan beberapa rebungnya dapat dikonsumsi sehingga bernilai ekonomis tinggi seperti, bambu betung (Dendrocalamus asper), bambu legi (Gigantochloa atter), bambu mayan (Gigantochloa robusta) yang banyak di jumpai di Sumatera dan bambu tabah (Gigantochloa nigrociliata) banyak dijumpai di Papua, Bali dan beberapa tumbuh di Sukabumi Jawa Barat (Widjaja, 2001).

Rebung memiliki nilai gizi cukup baik untuk dikonsumsi. Menurut Direktorat Gizi Departemen Kesehatan RI (1981) setiap $100 \mathrm{~g}$ rebung mengandung, $27 \mathrm{kkal}$ energi, $2.6 \mathrm{~g}$ protein, $0.3 \mathrm{~g}$ lemak, $5.2 \mathrm{~g}$ karbohidart, $13 \mathrm{mg}$ kalsium, $59 \mathrm{mg}$ fosfor, $0.5 \mathrm{mg}$ besi, $20 \mathrm{SI}$ vitamin $\mathrm{A}, 0.15$ $\mathrm{mg}$ vitamin $\mathrm{B} 1 \mathrm{dan} 4 \mathrm{mg}$ vitamin $\mathrm{C}$. Rebung merupakan makanan yang kaya akan serat dan sumber kalium yang baik sehingga dapat menurunkan kolesterol darah yang beresiko penyakit kardiovaskular. Namun, terdapat kandungan anti nutrisi rebung seperti kandungan senyawa Hidrogen Sianida (HCN) sekitar $50 \mathrm{mg} / \mathrm{kg}$ yang dapat membahayakan kesehatan (WHO/FAO Expert Consultation, 2003).

Berdasarkan penelitian sebelumnya yang dilakukan oleh Mar"eatun Soleha (2016) bahwa rebung dengan ukuran besar dengan tinggi $27 \mathrm{~cm}$ dan diameter $16 \mathrm{~cm}$ memiliki kadar HCN sebanyak 21,84 $\mathrm{mg} / \mathrm{kg}$, sampel rebung dengan ukuran sedang dengan tinggi $18 \mathrm{~cm}$ dengan diameter $7 \mathrm{~cm}$ dengan kadar $\mathrm{HCN}$ sebanyak $18,40 \mathrm{mg} / \mathrm{kg}$ dan rebung dengan ukuran kecil dengan tinggi $8 \mathrm{~cm}$ dengan diameter $4 \mathrm{~cm}$ dengan kadar $\mathrm{HCN} 4,65$ $\mathrm{mg} / \mathrm{kg}$ sehingga semakin besar ukuran rebung semakin besar pula kadar sianida yang terdapat pada rebung. Rebung yang mengandung sianida dapat menimbulkan rasa pahit yang menandakan bahwa kadar sianida pada rebung cukup tinggi. Konsumsi rebung dengan pengolahan yang kurang baik dapat mengakibatkan keracunan dan dapat berujung pada kematian (Andoko, 2003).

Sianida yaitu suatu cairan tidak berwarna yang mudah menguap, mendidih pada $260 \mathrm{C}$, dengan toksisitas yang sangat tinggi (LD: $1-2 \mathrm{mg} / \mathrm{kg} \mathrm{BB}$ oral) dan memiliki bau yang khas (Schmitz et al., 2004). Konsumsi senyawa ini secara berlebihan atau terus menerus akan berbahaya bagi tubuh manusia.

Gejala keracunan asam sianida ditandai dengan pernapasan yang semakin cepat, tekanan darah turun, mudah lelah, muntah, panalisis seluruh sel (kejang), pingsan dan koma (Pambayun dalam Ceria, A et al., 2017). Penurunan tingkat sianida dapat dicapai dengan beberapa metode pengolahan seperti perendaman dengan air, perendaman dengan larutan garam, memasak (perebusan, pengukusan) dan pengeringan (Murni et al., 2008).

Oleh karena itu, peneliti ingin mengetahui apakah terdapat pengaruh kadar sianida pada rebung berdasarkan proses perendaman.

\section{BAHAN DAN METODE Alat dan Bahan}

Alat yang digunakan adalah pisau, ember, blender, labu ukur $50 \mathrm{ml}, 100 \mathrm{ml}$, $250 \mathrm{ml}, 1000 \mathrm{ml}$, timbangan analitik, gelas ukur $100 \mathrm{ml}$, alat destilasi, alat spektrofotometer UV-Vis.

Bahan yang digunakan adalah sampel rebung, larutan $\mathrm{KCN}$, larutan AgNO3 0,1 M, NaCL, Indikator rhodamin, larutan indikator $\mathrm{K} 2 \mathrm{CrO} 45 \%$, larutan $\mathrm{NaOH} 2 \%$, larutan ammonium amidosulfat $10 \%$, larutan EDTA, Asam fosfat (H2PO4) $\mathrm{P}$, Asam asetat pekat, larutan indikator fenolftalein $0,5 \%$, larutan kalium dihidrogen fosfat $20 \%$, larutan baku fosfat pH 7,2, larutan kloramin-T, larutan HCL, larutan 4-piridin asam karboksilat- 
pirazolon/ asam barbiturat handscoon, masker, dan aquadest.

\section{Prosedur Penelitian}

\section{Pengambilan Sampel}

Sampel penelitian diambil secara langsung dari lahan warga di Kecamatan Bonto Ramba Kabupaten Gowa. Sampel diambil dengan kriteria berdasarkan jenisnya. Setelah pengambilan sampel selesai, dilakukan perlakuan pada sampel rebung yaitu dibersihkan, direndam dan dihaluskan kemudian dilakukan pengukuran kadar asam sianida.

\section{Pengolahan Sampel}

Sampel dikupas, kemudian dibersihkan, direndam, dipotong dan dihaluskan menggunakan blender dengan penambahan aquadest sebanyak $100 \mathrm{ml}$ untuk memudahkan penghalusan dan melarutkan sianida yang terkandung dalam sampel.

\section{Persiapan Pengujian Asam Sianida \\ (HCN) (Menurut SNI, 2003) \\ Destilasi Sampel}

Ditimbang 50 gr sampel yang telah dihaluskan dan masukkan kedalam labu didih, tambahkan aquadest hingga volume kurang lebih $200 \mathrm{ml}$, tambahkan 3 tetes larutan indikator fenolftalein $0,5 \%$, lalu ditambahkan ammonium amidosulfat $10 \%$ sebanyak $1 \mathrm{ml}$ sampai larutan bersifat asam. Ditambahkan lagi dengan asam phophat $10 \mathrm{ml}$, ditambahkan larutan EDTA $10 \mathrm{ml}$, pasang alat destilasi dan alat penampung destilat pada Erlenmeyer yang berisi $20 \mathrm{ml}$ larutan $\mathrm{NaOH} 2 \%$. Bilas injection funnel dengan aquadest. Alat destilasi dipanaskan dan kecepatan destilasi sekitar 2-3 ml/menit. Tampung destilat sampai kurang lebih $100 \mathrm{ml}$. bilas pendingin dengan aquadest.

\section{Pengujian Asam Sianida}

Optimalkan alat spektrofotometer untuk pengujian kadar sianida sesuai petunjuk penggunaan alat. Netralkan hasil destilat dengan HCL 1:1 sampai bersifat asam. Kemudian sampel dipipet $1 \mathrm{ml}$ masukkan kedalam labu ukur $100 \mathrm{ml}$ yang telah dicukupkan dengan aquadest sampai tanda tera. Lalu sampel yang telah dicukupkan dengan aquadest dipipet sebanyak $20 \mathrm{ml}$ dan dimasukkan kedalam gelas ukur lalu ditambahkan dengan $4 \mathrm{ml}$ larutan $\mathrm{NaH} 2 \mathrm{PO} 4$ lalu ditambahkan lagi dengan kloramin $\mathrm{T}$ sebanyak $2 \mathrm{ml}$ dan terakhir ditambahkan lagi dengan asam Barbipurat sebanyak $5 \mathrm{ml}$, lalu dikocok sampai berubah warna menjadi ungu keping pingan jika positif sianida, dimasukkan kedalam kuvet pada spektrofotometer, ukur dan catat absorbannya dengan panjang gelombang 606 nm. Selanjutnya dilakukan pengukuran yang sama pada Blanko.

Perhitungan

$$
\mathrm{CN}(\mathrm{mg} / \mathrm{kg})=\frac{\mathrm{a} \times \mathrm{b} \times \mathrm{fp}}{\mathrm{c}}
$$

Keterangan :

$\mathrm{a}=$ Konsentrasi sampel dari alat spektrofotometer

$\mathrm{b}=$ Sampel uji yang di destilasi (100ml) dijadikan ke liter

$\mathrm{c}=$ Berat sampel yang ditimbang dari gr dijadikan $\mathrm{kg}$.

$\mathrm{Fp}=$ faktor pengenceran.

\section{HASIL PENELITIAN}

Penelitian ini menggunakan metode eksperimen dengan analisa laboratorium menggunakan sampel rebung. Penelitian ini dilakukan di Laboratorium Kimia Balai Besar Laboratorium Kesehatan Kota Makassar dan diperoleh hasil seperti yang tertera pada tabel 1 . 
Tabel 1. Hasil Pemeriksaan Pengaruh Waktu Perendaman Pada Rebung Betung (Dendrocalamus asper) Terhadap Penurunan Kadar Sianida

\begin{tabular}{cc}
\hline $\begin{array}{c}\text { Waktu } \\
\text { Penyimpanan } \\
\text { (menit) }\end{array}$ & $\begin{array}{c}\text { Kadar } \\
\text { Sianida } \\
\text { (mg/Kg) }\end{array}$ \\
\hline 0 & 64.07 \\
15 & 49.78 \\
30 & 45.15 \\
45 & 44.85 \\
60 & 43.83 \\
\hline
\end{tabular}

PEMBAHASAN

Penelitian ini dilakukan di Balai Besar Laboratorium Kesehatan Makassar khususnya Laboratorium Kimia Lingkungan pada tanggal 30 April- 07 Mei 2018 dengan sampel rebung betung (Dendrocalamus asper) berdasarkan variasi waktu perendaman 0 menit, 15 menit, 30 menit, 45 menit dan 1 jam. Rebung berdasarkan jenis betung (Dendrocalamus asper) dengan ukuran 27 $\mathrm{cm}$ dan keliling lingkaran $16 \mathrm{~cm}$ diambil di daerah Bontoramba Kabupaten Gowa. Sebelum dilakukan pemeriksaan, rebung terlebih dahulu dikupas kulitnya, dibersihkan kemudian dipotong-potong. Untuk sampel A (control) tidak dilakukan perendaman tetapi langsung ditimbang kemudian di blender agar $\mathrm{CN}$ - yang terdapat pada sampel mudah terurai. Sampel B, C, D dan E masing-masing dilakukan perendaman dalam air dengan variasi waktu 15 menit, 30 menit, 45 menit dan 1 jam. Tujuan dilakukannya perendaman diharapkan agar kadar sianida pada sampel dapat menurun.

Berdasarkan data pengamatan uji kuantitatif Sianida (CN-) pada sampel rebung dengan menggunakan alat spektrofotometer UV-Vis diperoleh hasil yaitu pada sampel rebung betung (Dendrocalamus asper) dengan perendaman 0 menit didapatkan kadar sianida $64,07 \mathrm{mg} / \mathrm{kg}$ dengan selisih 0 , pada perendaman 15 menit didapatkan kadar sianida $49,78 \mathrm{mg} / \mathrm{kg}$ dengan selisih sebanyak 14,29, pada perendaman 30 menit didapatkan kadar sianida 45,15 $\mathrm{mg} / \mathrm{kg}$ dengan selisih sebanyak 18,92, pada perendaman 45 menit didapatkan kadar sianida 44,85 mg/kg dengan selisih sebanyak 19,22 dan pada perendaman selama 1 jam didapatkan kadar sianida $43,83 \mathrm{mg} / \mathrm{kg}$ dengan selisih sebanyak 20,24 .

Faktor yang mempengaruhi terdapat perbedaan kadar berdasarkan variasi waktu perendaman tersebut dikarenakan HCN yang ada di dalam sampel rebung dapat larut dalam air oleh karena itu semakin lama perendaman maka kadar HCN pada sampel semakin berkurang. Perendaman dengan air dapat merombak atau menguraikan $\mathrm{HCN}$ dari ikatan glikosida sianogenik, sehingga HCN banyak yang larut dan terbawa oleh air. Pada saat perendaman terjadi difusi. Difusi adalah peristiwa berpindahnya suatu zat dalam pelarut dari bagian berkonsentrasi tinggi kebagian konsentrasi rendah. Hal ini ditandai dengan kondisi air yang berubah warna atau berbuih. Di duga salah satu zat yang larut ini adalah $\mathrm{HCN}$ karena sifat $\mathrm{HCN}$ itu sendiri mudah larut dalam air (Kurniawan, 2012).

HCN dalam rebung sebanyak mungkin dihilangkan, karena $\mathrm{HCN}$ bersifat racun. Di dalam tubuh sianida yang dilepas dari dalam lambung, sebagai hasil hidrolisis glikosida sianogen, akan diserap dengan cepat kedalam aliran darah. Selanjutnya akan terjadi oksigenasi (level oksigen tinggi dalam darah) karena sianida bereaksi dengan ferric dari cytochrome oxidase dan membentuk cyanide chytochrome yang tinggi. Sementara itu, Hemoglobin tidak mampu membebaskan oksigen (system transportasi electron) sehingga warna darah menjadi terang, sebagai ciri spesifik keracunan sianida (Yuningsih, 2012).

Cara pemasakan/perebusan lebih efektif untuk menurunkan kadar sianida 
dibandingkan dengan perendaman. Melalui pemanasan, enzim yang bertanggung jawab terhadap pemecahan taxypylin menjadi inaktif dan hydrogen menyebabkan sianida tidak terbentuk (Winarno, 2007).

Menurut WHO/FAO Expert Consultation (2003) Kandungan HCN memiliki batas normal untuk dikonsumsi yaitu $<50 \mathrm{mg} / \mathrm{kg}$ dan pada penelitian ini diperoleh $\mathrm{HCN}$ tertinggi yaitu pada sampel A (control) sebanyak $64,07 \mathrm{mg} / \mathrm{kg}$ dimana melewati ambang batang yang telah ditentukan. Namun kadar tersebut diperoleh karena pada kontrol tidak dilakukan perendaman. Selanjutnya diperoleh kadar terendah pada waktu perendaman 1 jam dengan kadar $\mathrm{HCN}$ sebanyak 43,83 mg/kg. Kadar tersebut tidak melewati ambang batas karena kadar yang diperoleh tidak lebih dari $50 \mathrm{mg} / \mathrm{kg}$ sehingga rebung masih aman untuk dikonsumsi.

\section{KESIMPULAN DAN SARAN}

Berdasarkan hasil penelitian Pengaruh Waktu Perendaman Pada Rebung Betung (Dendrocalamus asper) Terhadap Penurunan Kadar Sianida dimana masing-masing kadar sianida rebung memiliki kadar berbeda yaitu pada kontrol memiliki kadar sianida tertinggi yaitu $64,07 \mathrm{mg} / \mathrm{kg}$, sampel $B$ dengan waktu perendaman 15 menit memiliki kadar $49,78 \mathrm{mg} / \mathrm{kg}$, sampel C dengan waktu perendaman 30 memiliki kadar $45,15 \mathrm{mg} / \mathrm{kg}$, sampel D dengan waktu perendaman 45 menit memiliki kadar $44,85 \mathrm{mg} / \mathrm{kg}$, sampel E dengan waktu perendaman 1 jam memiliki kadar 43,83 $\mathrm{mg} / \mathrm{kg}$ sehingga dapat disimpulkan bahwa waktu perendaman mempengaruhi kadar sianida pada rebung, semakin lama waktu perendaman maka kadar sianida pada rebung semakin menurun.

\section{DAFTAR PUSTAKA}

Andoko, A. 2003. Budidaya Bambu Rebung.Yogyakarta : Kanisius

Ceria, A.V, Syariful, A, Yonelian, Y, 2017. Jurnal Riset Kimia "Variasi
Waktu dan Cara Pengolahan Sebelum Dikonsumsi Terhadap Penurunan Kandungan Asam Sianida Pada Varietas Rebung Bambu Ampel (Bambusa Vulgaris)", Desember 2017.

Kurniawan, A., S.Y. Wulandari dan E. Supriyantini. 2012. Pengaruh Perebusan Abu Sekam dan Waktu Perendaman Air terhadap Kadar HCN Pada Buah Mangrove (Avicenia marina). Journal of Marine Research. Vol. I, No.2.

Murni R, Suparjo, Ginting A. 2008. Buku Ajar Teknologi Pemanfaatan Limbah Untuk Pangan. Jambi: Universitas Jambi.

Soleha Mar"atun, 2016. Analisis Kadar Sianida Pada Rebung Berdasarkan Volume Ukuran (KTI). Makassar: Akademi Analis Kesehatan Muhammadiyah Makassar.

WHO/FAO Expert Consultation. 2003. Diet, nutrition, and the prevention of chronic diseases. WHO,Geneva.

Winarno, F.G. 2007. Kimia Pangan dan Gizi. Jakarta: PT. Gramedia Pustaka Utama, Jakarta.

Widjaja, E. A. 2001. Identifikasi Jenisjenis Bambu. Pusat Penelitian dan Pengembangan Biologi-LIPI. Balai Penelitian Botani, Herbarium Bogorisense. Bogor.

Yuningsih, 2008. Kandungan dan Stabilitas Sianida Dalam Tanaman Picung (Pangium edule Reinw) Serta Pemanfaatannya. Balai Besar Penelitian Veteriner.102-109. 